Nig. J. Pure \& Appl. Sci. Vol. 33 (Issue 2, 2020)
eISSN 2756-4045
Life Sciences, Univ. of Ilorin, Nigeria
www.njpas.com.ng

http://dx.doi.org/10.48198/NJPAS/20.B02

\title{
POLLUTION POTENTIAL AND CHEMICAL INTERACTION OF SOME PHYSICOCHEMICAL PARAMETERS OF SOIL CONTAMINATED WITH E-WASTE
}

\author{
${ }^{* 1}$ EYENUBO, O.B., ${ }^{2}$ EGHAREVBA, F., ${ }^{2}$ ASIA, I. O. and ${ }^{3}$ OSAKWE, S.A.
}

\author{
Department of Science Laboratory Technology, Delta State University, Abraka, Nigeria. \\ Department of Chemistry Ambrose Alli University, Ekpoma, Nigeria, \\ Department of Chemistry, Edwin Clark University, Kiagbodo, Delta State, Nigeria.
}

\begin{abstract}
The rapid increase in the amount of electronic waste in our environment is of great concern. This study investigated the contamination level, pollution potential and chemical interaction of cation exchange capacity (CEC), total nitrogen (TN), total phosphorus (TP), electrical conductivity (EC), total organic carbon (TOC), total organic matter (TOM) and $\mathrm{pH}$, on soil contaminated with electronic waste and background soil (unpolluted soil). It was found that CEC has the highest pollution values, which range from 194,616.00(10-20 cm)- 221,024.760 $\mathrm{mg} / \mathrm{kg}(0-10 \mathrm{~cm})$ for the polluted soil, which show a remarkable variation from the background soil. The TN value range from $139.257-185.654 \mathrm{mg} / \mathrm{kg}$ across depths. The values of EC on polluted soil ranged from 0.260 $-0.746 \mathrm{mg} / \mathrm{kg}$ across depths. While that of TOC and TOM, ranged from 4,250.00 - 5,800.000 $\mathrm{mg} / \mathrm{kg}$ and $8,300.000-10,000.000 \mathrm{mg} / \mathrm{kg}$ across depths, the values of $\mathrm{pH}$ for the polluted soil also ranged from $6.2-7.1$ across depths. The pollution potential also showed high values across depths, the TOM, which ranged from $48.473-61.450$ and TOC are almost of the same ranged with the TOM. The TN and TP were very low and the EC exerted negative pollution potential in all the depths. The chemical interaction showed high values in TN which ranged from 12,776.708 - 9,419.512 across depths, followed by TP and CEC which also display high values, but lower than that of TN. The EC values were low, which ranged from $1.620-5.984$ across depths. The TOC and TOM were very low when compared to the rest parameter in the chemical interaction. The high values obtained in some of the parameters compared with the standard values, call for need for strict monitoring of the disposal of e-waste in our environment.
\end{abstract}

Keywords: Chemical interaction, concentration, e-waste, pollution potential physicochemical parameters.

\section{Introduction}

Electronic waste result from all electronic and electrical equipment which are made up of various items such as Televisions (TVs), DVD Players, Refrigerators, Washing machines etc (Pinto, 2008). E-waste is the most highly generated waste globally due to rapid advances and innovation in technology, which lead to high production of electronic equipment's (Robinson, 2009).

Over 500 million estimates of computers were reported obsolete between 1997 - 2007 in the united states alone, and an approximate of about 48 million tons of waste were generated in 2012, while 
above 50 million tons were generated annually worldwide (Huisman, 2012).

E-waste, arises as an environmental problem, due to its pollution ability, as it is made up of different mixture of metals, metalloid, glass and plastics.

Page | 3632 Some of these metals, such as copper, gold, aluminum, iron and silver are very useful and are recovered during recycling processes, thereby contributing to the remediation of polluted site with e-waste. In addition, e-waste contains hazardous substances such as $\mathrm{Cd}, \mathrm{Pb}, \mathrm{Ni}$, flame retardants etc, which are harmful to the environments where plants and animals dwell (Robinson, 2009).

Nigeria is one of the top most dumping grounds for e-waste. The amount of e-waste in Nigeria is significantly more than those of the neighboring countries (Efthymiou et al., 2016). Basel Action Network (BAN), a Seattle - based environmental reported that an estimate of 500 shipping containers with load equal in volume to 400,000 computer monitors and 175,000 of large TV sets enters Lagos.

Heavy metals found in e-waste polluted soil, such as $\mathrm{Cu}, \mathrm{Hg}$, and $\mathrm{Cd}$ are known to stay long in the environment, thereby accumulating in plants, animals and humans as a result of exposure to them. And these can cause problems to the nervous system (CDPHE,2008). The aim of this study was to assess the pollution potential, chemical interaction and the contamination levels of e-waste dump sites at Abraka, in Delta state, Nigeria.

\section{THEORY}

Following Egharevba and Odjada (2002), but with little modification. When an element or compound is found in an environment, it must display one form of reactivity or the other. As such, it will undergoes a change or cause a change in that particular environment. Given a waste material $\mathrm{A}_{\mathrm{g}}$ (pollutant) and a soil sample $\mathrm{B}_{\mathrm{g}}$, the pollution potential $(\gamma)$ of A and B depends on the concentration of A deposited on soil, the quantity of B taken for analysis and the chemical interaction of $A$ and $B\left(\sigma_{A B}\right)$. The pollution potential of $A$ on $B$ shows the level A can cause change in physicochemical properties of B.

From the above analogy, $\mathrm{dB}=\int\left([\mathrm{A}], 1 / \mathrm{M}_{\mathrm{B}}, \sigma_{\mathrm{AB}}\right)$

The applicable derivatives is the rate of change of $B$ with change in weight of $A$. Which can be define as

$\frac{\mathrm{dB}}{\mathrm{dA}}=\ln \frac{\Delta B}{\Delta A}$

As $\Delta \mathrm{A}=0$

When there is positive derivatives, the value of the function of $B$ increase with the value of $A$ and when the derivatives is negative, the value of the function of $\mathrm{B}$ decreases as $\mathrm{A}$ increases. Considering this, A becomes an independent variable and $\mathrm{B}$ is the dependent variable. Therefore, $\frac{\mathrm{dB}}{\mathrm{dA}}=\frac{\mathrm{dB}}{\mathrm{dA}}$

Rewriting equation (3),

$\mathrm{dB}=\frac{\mathrm{dB}}{\mathrm{dA}} . \mathrm{dA}$

This equation explains that as the value of $\mathrm{B}$ changes, $\mathrm{dB}$ is equal to the rate of change with respect to $\mathrm{A}, \mathrm{dB} / \mathrm{dA}$, multiplied by $\mathrm{dA}$, the change in $A$ when a change is made in $A$ from $A_{1}$ to $A_{2}$, the total change in $\mathrm{B}$ is achieved by integration.

$\int_{B_{1}}^{B_{2}} d B=\int_{A_{1}}^{A_{2}} \frac{d B}{d A} \cdot d A$

$B_{2}-B_{1}=\int_{A_{1}}^{A_{2}} B^{\prime}[A] d A--------------(6)$

where $B_{2}$ and $B_{1}$ are the values of $B$ obtained in the analysis corresponding to $\mathrm{A}_{2}$ and $\mathrm{A}_{1}$.

Resulting from this equation,

$\gamma=\frac{d B}{\lceil\mathrm{~A}\rceil}=\sigma_{\mathrm{AB}} \cdot \frac{1}{\mathrm{M}_{\mathrm{B}}}$

where $\mathrm{dB}$ is a change in physicochemical properties $B, W_{B}$ is the weight of polluted soil used for the analysis. The negative sign assumes a negative tendency of A to reduce the quality of the soil, $\sigma_{\mathrm{AB}}$ serve as the chemical interaction parameter of A and B. Hence $\gamma$ depicts the 
capability ot A to decrease the value of a desired property of the recipient soil.

Rearranging equation (7), gives

Page | $3633 \frac{\mathrm{dB}}{1 / \mathrm{M}_{\mathrm{B}}} \sigma_{\mathrm{AB}} \cdot[\mathrm{A}]$

$$
\begin{aligned}
& \mathrm{dB} \cdot \mathrm{M}_{\mathrm{B}}=-\sigma_{\mathrm{AB}} \cdot[\mathrm{A}] \\
& \mathrm{M}_{\mathrm{B}}\left(\mathrm{B}_{2}-\mathrm{B}_{1}\right)-\sigma_{\mathrm{AB}} \cdot[\mathrm{A}] \\
& \frac{\mathrm{B}_{2}-\mathrm{B}_{1}}{\lceil\mathrm{~A}\rceil}=-\frac{\sigma_{A B}}{\mathrm{M}_{B}} \\
& \frac{-\left(\mathrm{B}_{2}-\mathrm{B}_{1}\right)}{\lceil\mathrm{A}\rceil}=\frac{\mathrm{B}_{1}-\mathrm{B}_{2}}{\lceil\mathrm{~A}\rceil} \sigma_{\mathrm{AB}}\left(1 / \mathrm{M}_{\mathrm{B}}\right)
\end{aligned}
$$

$\delta_{\mathrm{AB}}$ may be however obtained as the product of the pollution potential and the weight of the recipient soil used for the analysis ie $\sigma_{\mathrm{AB}}=\gamma \mathrm{W}_{\mathrm{B}}$.

\section{Materials and Methods}

The equipment/apparatus and reagents used for the collection, treatment and analysis of the sample include; Meter rule, polythene bags, soil auger, $\mathrm{pH}$ meter (H198107), analytical weighing balance (MT-2000), fume cupboard, hot plate (LSC), atomic absorption spectrphotometer (perkin Elmer 1100), mesh sieve (2mm), electrical conductivity meter (data logging sper scientific), mortar and pestel, $0.01 \mathrm{M} \mathrm{Kcl}$ solution, $\mathrm{K}_{2} \mathrm{Cr}_{2} \mathrm{O}_{7}, \mathrm{H}_{2} \mathrm{SO}_{4}, \mathrm{FeSO}_{4}$, $\mathrm{K}_{2} \mathrm{SO}_{4}, \mathrm{H}_{3} \mathrm{BO}_{3}, \mathrm{NaOH}$, distilled water, $100 \mathrm{ml}$ measuring cylinder, $100 \mathrm{ml}$ volumetric flask and $250 \mathrm{ml}$ beaker.

\section{Study area}

Sample collection was done in May, at Abraka, in Delta state, Nigeria. The sampling point is along old Agbor Sapele Road, in Ajalomi, which is between Ajalomi community and campus 11 in Abraka. The study area has a coordinate of Latitude $06.23^{\prime} 0145^{\circ}$ $\mathrm{N}$ and Longitude 007.73'09 80 E (GPSMAP 64).

\section{Sample collection}

Soil sample were collected from e-waste dump site of dimension $15 \times 20 \mathrm{~cm}$. Before the deposition of the pollutant, the soil was analyzed as the background sample. The collection was done after three months of deposition with the help of soil auger at the depth of 0-10, 10-20, 20-30 and 30-40 $\mathrm{cm}$. These samples were poured carefully into a polythene bags and conveyed to the laboratory where they were homogenized by manual mixing. They were spread on a white sheet of paper to dry for 5 days. Thereafter, they were ground into fine powder with the use of mortar and pestle, sieved with a $2 \mathrm{~mm}$ mesh sieve and then stored in other sets of polythene bags.

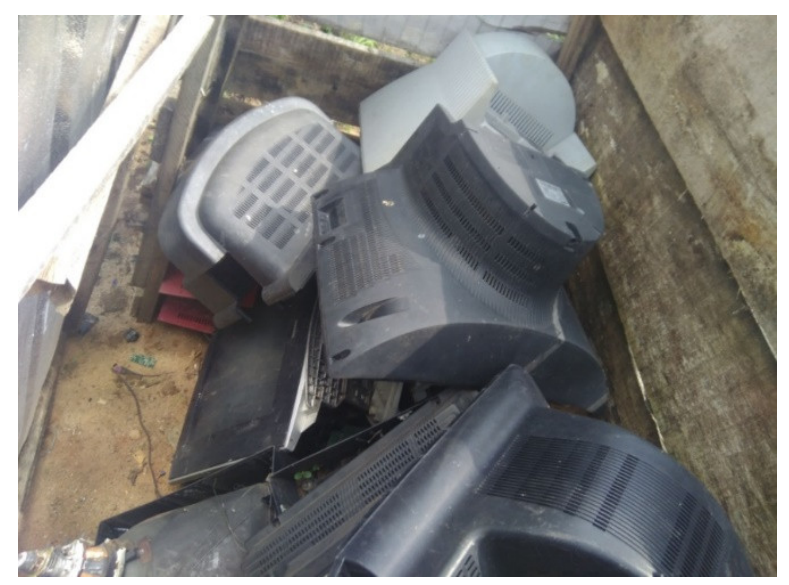

(a)

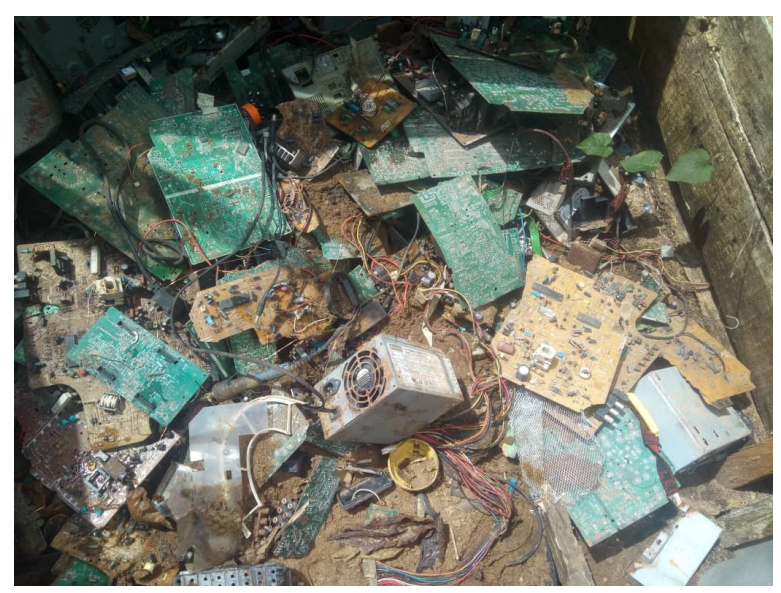

(b)

Figure 2 (a) \& (b): Electronic Waste Dumpsite in Abraka

Sample treatment and chemical analysis 
Determination of soil $\mathbf{p H}$ : This was done at ratio 1:2 soil/water, $20 \mathrm{gm}$ of air-dry soil was weighed into a $50 \mathrm{ml}$ beaker and $40 \mathrm{ml}$ of distilled water was added and allowed to stand for 30 minutes. Thereafter it was stirred with a glass rod, and then Page | 3634 the glass electrode of the $\mathrm{pH}$ meter was inserted after calibration with standard buffer solution of $\mathrm{pH}$ 4.0 and 9.2, and the reading were taken (Bhanttacharyya, et al., 2015)

Determination of Total Organic Carbon (TOC)
and total organic matter (TOM), (using Bhanttacharyya, et al., 2015) : $0.5 \mathrm{gm}$ of soil sample was treated with $10 \mathrm{ml}$ of $1 \mathrm{~N} \mathrm{~K}_{2} \mathrm{Cr}_{2} \mathrm{O}_{7}$ and $20 \mathrm{ml}$ of conc. $\mathrm{H}_{2} \mathrm{SO}_{4}$ and it was swirled gently and then vigorously for 1 minute and allowed to cool for 30 minutes before adding $20 \mathrm{ml}$ of distilled water and 3 drops of ortho-phenenthroline indicator. The content was titrated with $0.5 \mathrm{~N} \mathrm{FeSO}_{4}$ and as the end point was approaching, the solution took a greenish cast and then changed to dark green. $0.5 \mathrm{~N}$ $\mathrm{FeSO}_{4}$ was added drop wise until the colour change sharply from blue to red. The blank was also done in the same way, but without soil (Bhanttacharyya, et al., 2015.)

Calculation is as follow,

$\%$ organic carbon $=10(\mathrm{~S}-\mathrm{T}) \times 0.003 / \mathrm{S} \times 100 / \mathrm{Wt}$. of soil.

Where,

$\mathrm{S}=$ milliliters of $\mathrm{FeSO}_{4}$ solution required for blank

$\mathrm{T}=$ milliliters of $\mathrm{FeSO}_{4}$ solution required for soil sample

$0.003=$ weight of $\mathrm{C}\left(1000 \mathrm{ml} 0.1667 \mathrm{M} \mathrm{K}_{2} \mathrm{Cr}_{2} \mathrm{O}_{7}=3\right.$ g C. Thus, $1 \mathrm{ml} 0.1667 \mathrm{M} \mathrm{K}_{2} \mathrm{Cr}_{2} \mathrm{O}_{7}=0.003 \mathrm{~g} \mathrm{C}$ )

$\%$ organic matter in soil $=\%$ organic carbon $\mathrm{x}$ 1.729 .

Determination of electrical conductivity: $10 \mathrm{~g}$ of the sieved soil sample was weighed into $50 \mathrm{ml}$ beaker, followed by the addition of $25 \mathrm{ml}$ of distilled water and equilibrated for 30 minutes and then stirred. The EC meter electrode rinsed with distilled water was inserted into the partly settled suspension and the reading were displayed on the read-out unit.

Determination of total phosphorus: This was done following Olusen's method (2002).

Determination of total Nitrogen $\left(\mathrm{NH}_{4} \mathrm{~N}\right)$ : This was done using Kjedahl method 2002.

\section{Results and Discussion}

The mean concentrations of the physicochemical parameters of the e-waste polluted soil are presented on table $1 \& 2$ and also on figures $2 \& 3$.

Table 1: The mean concentration of some physicochemical parameters of the soil polluted with e-waste.

From table 1, it was found that cation exchange capacity (CEC) had very high values of pollution in all the depths when compared to WHO limit value of $1000.00 \mathrm{mg} / \mathrm{kg}$ (Orjiakor and Atuanya, 2015). They ranged from $194,616.000 \mathrm{mg} / \mathrm{kg}(10-20 \mathrm{~cm})$ $227,024.760 \mathrm{mg} / \mathrm{kg}(0-10 \mathrm{~cm})$, this call for alarm since the value are far higher than the WHO values. These values are high and this might be as a result of high content of organic matter and nutrient tightly bonded to the soil particles (Lancrop, 2013.). It has been shown that high CEC level in soil counts on the texture of soil and the content of organic matter (Ashraf et al., 2012). There is strong positive relationship between the total organic matter (TOM) and CEC. There was corresponding increase in the TOM values as the CEC values increased. Also, it was observed that the total organic carbon content (TOC) was also high when compared to WHO value of $1,720.00 \mathrm{mg} / \mathrm{kg}$ (Orjiakor and Atuanya, 2015). They ranged from $4,250.00-5,800.00 \mathrm{mg} / \mathrm{kg}$, which also call for alarm. This might be due to a high amount of rainfall, which also affect the soil $\mathrm{pH}$. The $\mathrm{pH}$ values reduced in the polluted soil, when compared with the background soil (unpolluted), it ranged from $6.2-7.1$ in background soil and $5.2-5.6$ in 
polluted soil, across the depths. Similar observation was reported by Salman et al. (2019). The positive pollution potential found in CEC was the highest; $384.780(0-10 \mathrm{~cm}), 340.260(10-20$ $\mathrm{cm}), 391.140(20-30 \mathrm{~cm})$ and $402.800(30-40 \mathrm{~cm})$, Page | 3635 followed by those of TOM and TOC. The values of total nitrogen (TN) and total phosphorus (TP) were low, when compared to WHO values of 4,500.00 and 5,000.00 mg/kg (Orjiakor and Atuanya, 2015). They ranged from $139.26-185.65 \mathrm{mg} / \mathrm{kg}$ and $60.73-84.88 \mathrm{mg} / \mathrm{kg}$ respectively. The result also displayed that the electrical conductivity exerted a negative soil pollution potential by the e-waste contaminants. The negative values found in electrical conductivity (EC) implies that the soil conductivity ability was not affected, while the positive pollution potential observed on other parameters showed that there was substantial impact by the e-waste contaminant. The plot of pollution potential across depths for the physicochemical parameters are presented in figure 2 (a) and (b). The plot of chemical interaction across depths for the physicochemical parameters are presented in figure 3 (a) and (b).

Table 1: The mean concentration of some physicochemical parameters of the soil polluted with e-waste

\begin{tabular}{|c|c|c|c|c|}
\hline \multirow[t]{2}{*}{ PARAMETER } & \multicolumn{4}{|c|}{ DEPTH (cm) } \\
\hline & $0-10$ & $10-20$ & $20-30$ & $30-40$ \\
\hline CEC $(\mathrm{mg} / \mathrm{kg})$ & $227,024.760 \pm 476.471$ & $194,616.00 \pm 441,153$ & $216,392.640 \pm 465.180$ & $221,713.840 \pm 470.865$ \\
\hline TN (mg/kg) & $156.567 \pm 8.847$ & $141.148 \pm 8.411$ & $185.654 \pm 9.635$ & $139.257 \pm 8.344$ \\
\hline TP (mg/kg) & $69.005 \pm 5,875$ & $78.287 \pm 6.257$ & $84.878 \pm 6.515$ & $60.733 \pm 5.511$ \\
\hline $\mathrm{EC}(\mathrm{mg} / \mathrm{kg})$ & $0.598 \pm 0.423$ & $0.260 \pm 0.184$ & $0.746 \pm 0.527$ & $0.349 \pm 0.246$ \\
\hline TOC (mg/kg) & $5,200.000 \pm 72.111$ & $4,250.000 \pm 65.192$ & $5,800.000 \pm 76.158$ & $4,800.000 \pm 69.282$ \\
\hline TOM (mg/kg) & $8,950.000 \pm 94.604$ & $7,350.000 \pm 85.731$ & $10,000.000 \pm 100.000$ & $8,300.000 \pm 91.104$ \\
\hline $\mathrm{Ph}$ & $7.10 \pm 14.07$ & $6.50 \pm 12.88$ & $6.50 \pm 12.88$ & $6.20 \pm 12.29$ \\
\hline
\end{tabular}

Table 2: The mean concentrations of some physicochemical parameter of the background soil (unpolluted)

\begin{tabular}{|l|l|l|l|l|}
\hline \multirow{2}{*}{ PARAMETER } & \multicolumn{5}{|}{ DEPTH (cm) } \\
\cline { 2 - 5 } & $\mathbf{0 - 1 0}$ & $\mathbf{1 0 - 2 0}$ & $\mathbf{2 0 - 3 0}$ & $\mathbf{3 0 - 4 0}$ \\
\hline CEC $(\mathrm{mg} / \mathrm{kg})$ & $21,435.320 \pm 146.408$ & $14,019.560 \pm 118.470$ & $11,655.960 \pm 107.963$ & $10,733.560 \pm 103.603$ \\
\hline TN $(\mathrm{mg} / \mathrm{kg})$ & $72.605 \pm 6.025$ & $66.735 \pm 5.776$ & $68.820 \pm 5.823$ & $77.380 \pm 6.220$ \\
\hline TP $(\mathrm{mg} / \mathrm{kg})$ & $20.575 \pm 3.207$ & $16.240 \pm 2.850$ & $16.075 \pm 2.835$ & $19.095 \pm 3.089$ \\
\hline EC $(\mathrm{mg} / \mathrm{kg})$ & $5.120 \pm 2.263$ & $2.560 \pm 1.810$ & $2.624 \pm 1.855$ & $2.976 \pm 2.104$ \\
\hline TOC $(\mathrm{mg} / \mathrm{kg})$ & $500.000 \pm 22.361$ & $550.000 \pm 23.452$ & $550.000 \pm 23.452$ & $250.000 \pm 31.623$ \\
\hline TOM $(\mathrm{mg} / \mathrm{kg})$ & $900.000 \pm 60.000$ & $1000.000 \pm 63.246$ & $950.000 \pm 30.822$ & $450.000 \pm 21.213$ \\
\hline $\mathrm{pH}$ & $5.50 \pm 14.20$ & $5.60 \pm 14.46$ & $5.20 \pm 13.43$ & $5.20 \pm 13.43$ \\
\hline
\end{tabular}


Page | 3636

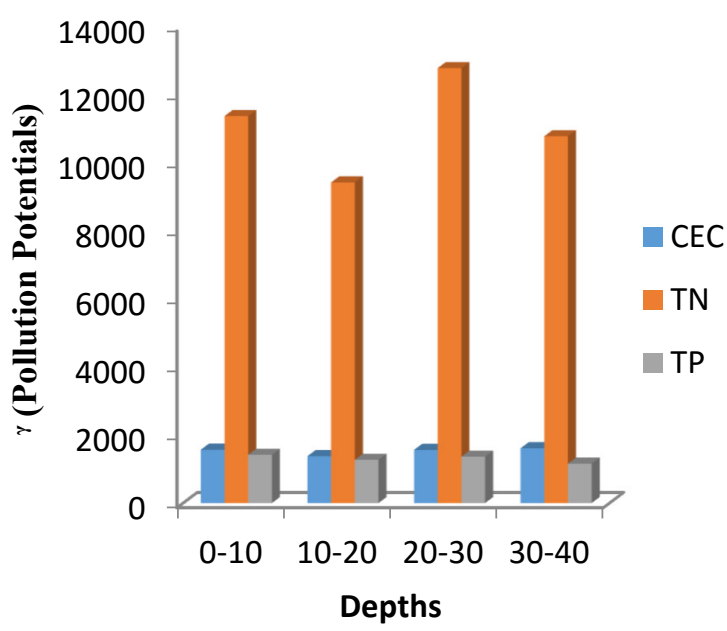

Key: $\mathrm{CEC}=$ Cation exchange capacity, $\mathrm{TN}=$ Total Nitrogen, TP = Total phosphorus

(a)

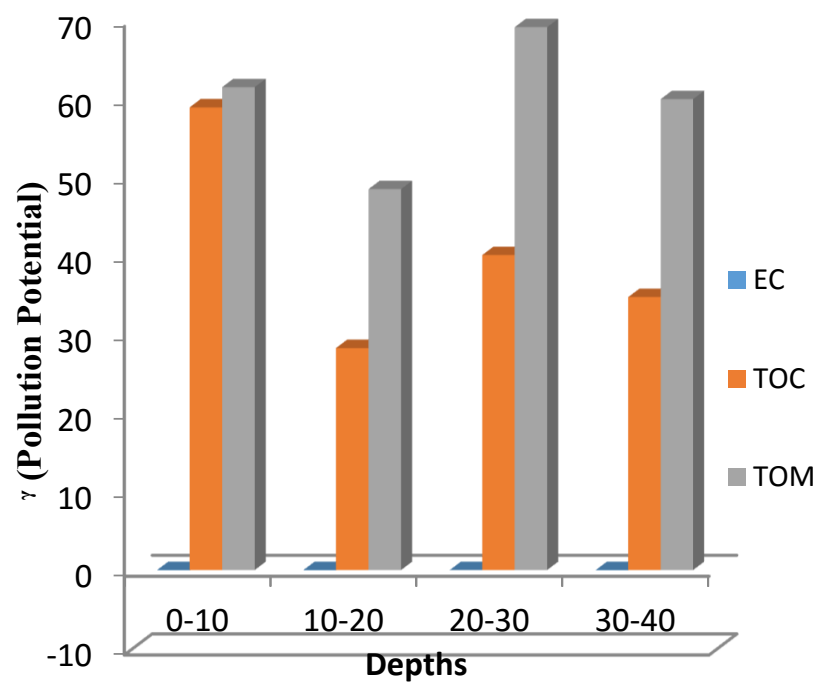

Key: $\mathrm{EC}=$ Electical conductivity, $\mathrm{TOC}=$ Total organic carbon, TOM $=$ Total organic matter

(b)

Fig 2(a) and (b): The plot of pollution potential versus depths for the physicochemical parameters.

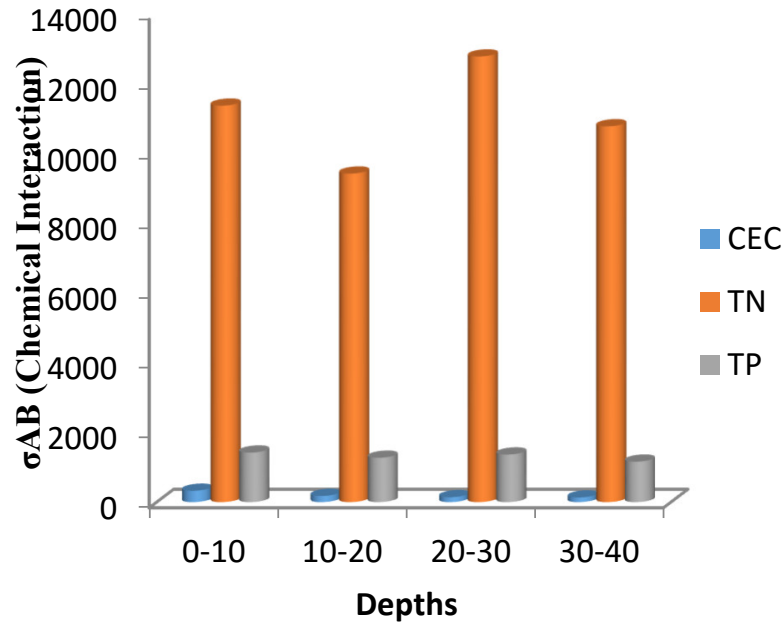

Key: $\mathrm{CEC}=$ Cation exchange capacity, $\mathrm{TN}=$ Total Nitrogen, $\mathrm{TP}=$ Total phosphorus

(a)

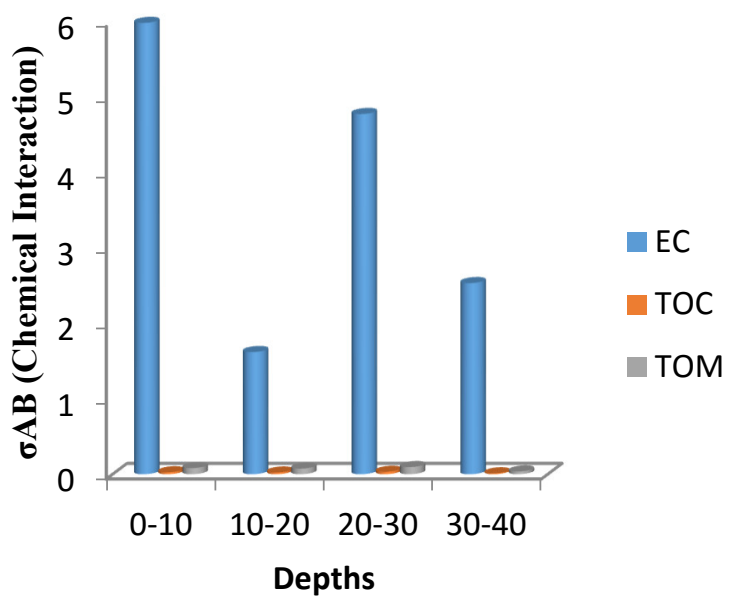

Key: $\mathrm{EC}=$ Electical conductivity, $\mathrm{TOC}=$ Total organic carbon, $\mathrm{TOM}=$ Total organic matter

(b)

Fig 3 (a) and (b): The plot of the chemical interaction versus depth of the physicochemical parameters. 
From the plot in figure 2 (a) and (b), it was noticed that $\mathrm{TN}$ has the highest values of pollution potential in plot (a) at depth 20-30 cm, CEC and TP were of the same range, while TOM at depth 20-30 cm displayed the optimum values in plot (b) followed by TOC at depth $0-10 \mathrm{~cm}$, while EC displayed negative pollution potential. At depth 10-20 cm, CEC exert the minimum pollution potential and at depth $30-40 \mathrm{~cm}$, it exerted the highest pollution potential. This might be as a result of weak binding ability between the soil and the e-waste contaminants at depth $10-20 \mathrm{~cm}$ and high binding capacity at depth $30-40 \mathrm{~cm}$, since the soil has a poor drainage system. Ashraf et al. (2012) reported that CEC count on soil texture and the content organic matter found in the soil, as a result, it can bind strongly to the soil, indicating that there is a greater capacity of the soil to hold cations strongly when there much of organic matter (Hazleuton, 2007). The TN values for the pollution potential were high throughout all the depths i.e. it ranged from 9,419.512 - 12,776.710, and the minimum value was found at depth 10-20 $\mathrm{cm}$, while the optimum values were found at depth $20-30 \mathrm{~cm}$. This might be due to the high content of organic matter present in the soil, due to the presence of some pieces of wood and dead decaying grasses (Noma and Taiwo, 2010), leading to high binding capacity to the pollutant of the e-waste.

The TP values were also high in all the depths. The values ranged from 1,159.697 - 1,419.978. The minimum value was found at depth $30-40 \mathrm{~cm}$. This might be as a result of low organic matter present at that level, which led to weak binding capacity of the soil. The optimum value was noticed at depth $0-10 \mathrm{~cm}$, and this may also be due to high level of organic matter present at that level, which led to high binding capacity of the soil to the e-waste contaminant.

The values of EC displayed negative pollution potential across all the depths, this might be due to minimal soil fertility or minimal nutrient availability (Noma and Taiwo, 2010), as such, it leads to low binding strength between the soil and the e-waste contaminant. Therefore, good soil fertility will increase EC level within the soil (Noma and Taiwo, 2010).

The TOC showed a high concentration across all the depth (figure 2(b)), but the optimum value was found at depth $10-20 \mathrm{~cm}$ and the least value was found at depth $10-20 \mathrm{~cm}$, this might be due to poor drainage system, which led to a strong binding capacity between the soil and the e-waste contaminant. The TOM exert a higher value more than the TOC, the optimum was found at depth 20-30 $\mathrm{cm}$ and the least at depth $10-20 \mathrm{~cm}$. This may be as a result of high organic matter content and rainfall, which led to increase in binding strength of the soil to e-waste contaminant.

The chemical interaction values were also high in selected parameters like TP, TN and CEC at different depths (table 2). This implies that there is high retention capacity of water, because of the poor drainage system at the dumping site. In selected parameters like EC, TOC and TOM, the values were low, which might be due to low concentration of organic matter content of the soil.

\section{Conclusions}

The fact that the contamination level of the soil is visible in this study with regards to CEC, TN, TP. EC. TOC, TOM and $\mathrm{pH}$, showed that there was considerable interaction between the components of e-waste and the soil particle. This led to the increase in the pollution level, pollution potential and chemical interaction, except for EC, which showed negative pollution potential. It is hereby 
recommended that monitoring of e-waste disposal in our environment should be encouraged.

\section{References}

Page | 3638

Ashraf, M., Maah, M. and Yusoff, I. (2012). Chemical speciation and potential mobility of heavy metals in the soil of formal tin mining catchment. The Scientific World Journal 1: 1 - 11 .

Bhattacharyya, T., Chandran, P., Ray, S. K., Mandai, C., Tiwary, P., Pal, D. K., Maurya, UK., Nimkar, A.M., Kuchankar, H., Sheikh, S., Telpande, B. A.and Ashwini, K. (2015). Walkley-Black recovery factors to reassess soil organic matter: Indo Gangetic plains and black soil region of India case study. Communications in soil science and plant analysis, 46.

Colombia Department of public health and environment (CDPHE), (2008). Fact sheet: Evaluation of onsite surface soil exposures by recreational users of standard MineGunmision country, Colorado. The Colorado cooperative program for environmental health assessment, Colombia.

Efthymiou, L., Mavragani, A. and Tsagarakis, K. P. (2016). Quantifying the effect of macroeconomic and social factors on illegal e-waste trade. International Journal of Environmental Research and Public health. 13 (789): 1-13.

Egharevba, F. and Odjada, V. (2002. The pollution potential and chemical interaction parameter of some Agro and industrial waste on soil. Nigeria journal of Basic and Applied Science, 11: 177 - 188.

Hazleton and Murphy (2007). Cation exchange capacity and its optimal ranges. Sectrum Analytical Inc. www.soilquality.org.au/fact sheet/cation-exchange-capacity. http://ipsnews.net/news.asp?idnews=40893.

Huisman, J. (2012). Eco-efficiency evaluation of waste electrical and electronics take-back system. In V. good-ship and A. Steels waste electrical and electronic handbook. Wood Head Publishing. 93-119.

Landcrop, L. (2013). http//varvita.com/content/ lancrop-en.aspx [online] Available at: htt://www.lancrop.com/content/lancrop-enaspx.

Nimet (2014). Animal climate review bulletin, retrieved from http ://nimet.gov.ng/annualclimate-review [Acessed $11^{\text {th }}$ January, 2016].

Noma andTaiwo, O. (2010). Ecological effects of electronic waste in electrical conductivity of soil. Research Journal of Chemical Science, 2 (1): $14-21$.

Orjiakor, P.I. and Atuanya, E.I. (2015). Effects of authomobile battery waste on physicochemical properties of soil in Benin City, Edo State. Global journal of pure and applied science, 21: $129-136$.

Pinto, V.N. (2008). E-waste hazard: The impending challenge, Indian J. Occup. Environ. Med. 12 (2): 65-70.

Robinson, B. H, (2009). E-waste: An assessment of global production and environmental impact. Science of the total Environment. 408:183-191.

Salman, A. S., Salah, A.M.Z., El-Montser, M. S. and Mahmoud, A. A. (2019). Soil characterization and heavy metal pollution assessment in orabi farms, El Obour, Egypt. Bulletin of the National Research Centre, 43 (42): 1- 13. 